\title{
Do Investors Flip Less in Bookbuilding than in Auction IPOs?
}

\author{
Suman Neupane ${ }^{a^{*}}$ Andrew Marshall ${ }^{b}$ Krishna Paudyal ${ }^{b}$ Chandra Thapa $^{b}$
}

\begin{abstract}
This paper examines whether investors flip their allocation less in bookbuilding than in auction IPOs. Based on bookbuilding theory, we posit that the ability to control allocation flexibility in the bookbuilding mechanism should enable underwriters to avoid flippers and target long-term investors. Consistent with this premise, we find that investors flip significantly less in bookbuilding IPOs, both in overall terms and separately for frequent and non-frequent investors. Frequent investors flip considerably less in IPOs that are managed by reputed underwriters and in IPOs that are weak. Both frequent as well as non-frequent investors in bookbuilding IPOs continue to hold their shares for much longer than investors in auction IPOs. The results highlight the benefits of allocation discretion which allows underwriters to influence investors' behaviour as well as use soft non-bid information in the IPO process.
\end{abstract}

Keywords: flipping, bookbuilding, auction, IPO, Indian IPOs, allocation discretion JEL Classification: G24, G32

This version: 18 May, 2016

\footnotetext{
* Corresponding Author

a Department of Accounting, Finance and Economics, Griffith Business School, Nathan campus, Griffith University, Nathan QLD 4111, Australia. Email: s.neupane@griffith.edu.au. Tel: +61 73735 3500, fax: +61 7 37353719

b Department of Accounting and Finance, University of Strathclyde, Scotland G4 OLN, United Kingdom.
} 


\section{Introduction}

Several studies have attempted to identify the most efficient method of allocating initial public offerings (IPOs). ${ }^{1}$ Despite some criticism, bookbuilding has become the leading selling mechanism around the world (Jagannathan et al., 2015).The debate on bookbuilding surrounds the discretionary power given to bookbuilding underwriters which allows them to exercise discretion in allocating shares to the investors. Proponents of bookbuilding argue that this discretion allows underwriters to extract information and incorporate non-bid information from investors, thus helping to increase the pricing efficiency of the IPO (Benveniste and Spindt, 1989; Benveniste and Wilhelm, 1990; Sherman, 2000). On the other hand, critics of bookbuilding argue that the discretionary power allows underwriters to develop relations with investors for their mutual benefit (Loughran and Ritter, 2004; Nimalendran et al., 2007; Ritter, 2011). A few studies (Degeorge et al., 2007; Kutsuna and Smith, 2004; Lowry et al., 2010) have compared valuation efficiency and other pricing issues across bookbuilding and auction/fixed price mechanisms. However, no study, to the best of our knowledge, has compared flipping across different allocation mechanisms. ${ }^{2}$

The degree of flipping by initial IPO investors is important to both issuers and underwriters. Aggarwal (2003) argues issuers want their shares to be allocated to long term investors ("strong hands"). Similarly, underwriters would prefer that their IPOs do not have significant levels of flipping as this poses difficulties in stabilizing the IPO market, particularly of those IPOs with weak demand (Ellis, 2006). Thus, identification of an IPO

\footnotetext{
${ }^{1}$ Bookbuilding, fixed price and auction mechanisms have been the three most commonly used mechanisms, although bookbuilding has become the most dominant in recent times. See Jagannathan et al. (2015) for a detailed discussion of the various allocation mechanisms and other issues associated with them.

${ }^{2}$ Flipping refers to selling of IPO shares by investors in immediate period after the listing. Although prior studies have looked at flipping in bookbuilding Aggarwal R. Allocation of initial public offerings and flipping activity. Journal of Financial Economics 2003;68; 111-135, Krigman L, Shaw W, Womack K. The persistence of IPO mispricing and the predictive power of flipping. Journal of Finance 1999;54; 1015-1044 and auction Degeorge F, Derrien F, Womack K. Auctioned IPOs: The US Evidence. Journal of Financial Economics 2010;98; 177-194 IPOs separately, no prior study has compared flipping in these two mechanisms.
} 
mechanism that minimises flipping should be in the interest of both issuers and underwriters. The main aim of our paper is to examine whether underwriters use the discretionary power allowed in the bookbuilding mechanism to place shares with investors who are less likely to flip their shares. In addition to the primary research question, we also develop other hypotheses (see section 2) based on the bookbuilding theory, which consider the implications of the long-term relationship between underwriters and regular/frequent investors (Benveniste and Spindt, 1989; Sherman, 2000).

We examine these hypotheses in the Indian IPOs market that offers an ideal setting to test the flipping behaviour of investors in bookbuilding and auction IPOs for the following reasons. First, in late 2005, after a few years of experimentation with a modified form of bookbuilding mechanism, which allowed underwriters to exercise discretion in allocating shares to institutional investors, Indian regulators abandoned it in favour of a uniform price auction mechanism. ${ }^{3}$ The auction regime stripped underwriters of their discretionary allocation power. Therefore, the availability of flipping data on bookbuilding and auction regimes in this short time interval, pre- and post-regulatory change periods, allows us to examine the effectiveness of the two mechanisms in reducing flipping in a quasi-natural experimental setting. ${ }^{4}$

Second, the Indian setting also provides us with a unique database which allows us to track every single trade made by foreign institutional investors (FII, hereafter). This publicly available database from the Securities and Exchange Board of India (SEBI, hereafter) contains every FII trade made since 2003 . We are able to track every single allocation to FII

\footnotetext{
${ }^{3}$ See Bubna and Prabhala (2011) and Neupane S, Poshakwale S. Transparency in IPO Mechanism: Retail investors' participation, IPO pricing and returns. Journal of Banking and Finance 2012;36; 2064-2076 for a detailed description of the two regimes relevant to our study.

4 Bubna A, Prabhala NR. IPOs with and without Allocation Discretion: Empirical Evidence. Journal of Financial Intermediation 2011;20; 530-561 use this setting to investigate pre-market price discovery, underpricing, bidding and allocation and show that in bookbuilding underwriters extensively exercise discretion in allocation. Our study differs substantially from theirs, but complements their findings on discretionary role of underwrites, as we examine the role of discretion on flipping in the post-IPO trading period.
} 
from the date of IPO allocation to the time they are finally sold. ${ }^{5}$ Although a subset of the overall IPO allocation, FII constitute one of the largest institutional investor categories - they receive about 50 percent of the institutional allocation which translates into about 25 percent of the total shares offered in the IPO. Our sample consists of 45 bookbuilding and 58 auction Indian IPOs, all issued during a three-year window between 2004 and 2006. We identify a total of 3,009 individual FII allocations for these 103 IPOs and initially analyse flipping in the first three days of listing.

Several important findings emerge from this study. First, reflecting the implications of discretionary allocation ability of underwriters, we find that investors flip significantly less in bookbuilding than in auction IPOs. Second, our result holds for both frequent and nonfrequent IPO investors. Consistent with the view that bookbuilding allows underwriters to develop long-term relations with investors; we find that frequent investors not only flip significantly less in IPOs managed by high reputation underwriters, but also in IPOs with weak demand. Given that both bookbuilding and auction regimes have the same set of frequent investors and high reputation underwriters, our evidence suggests that the withdrawal of allocation powers in the auction regime brought about a significant change in the flipping behaviour of these investors. As Indian underwriters extensively exercised allocation discretion when permitted to do so (Bubna and Prabhala, 2011), our result suggests that investors valued and considered such discretion when flipping their shares. Further, low levels of flipping by non-frequent investors in bookbuilding implies that the discretionary power enables the underwriters to target investors who are less likely to flip. Finally, we also find less flipping in bookbuilding over the longer term in post IPO trading in periods up to six months after listing. The evidence shows a significant difference in long-term holdings across

\footnotetext{
${ }^{5}$ We describe this database in detail in Section 3.
} 
the two IPO mechanisms for both frequent and non-frequent investors with the effect stronger in IPOs managed by high reputation underwriters for frequent investors.

Our paper makes two contributions to the IPO literature. First, it offers new evidence on the flipping behaviour of investors across the two main IPO allocation mechanisms. We contribute to the debate on the efficiency of IPO mechanisms and show that giving underwriters allocation discretion can help reduce flipping by IPO investors. Second, we also present evidence on the less discussed non-frequent investors participating in IPOs. Our evidence suggests that the discretionary power allows underwriters to target and preferentially allocate shares to long-term investors who might be of strategic interest to the firm involved. At the very least, the significant exit of long-term investors with the change of regime suggests that the presence of allocation flexibility encourages long-term investors to selectively participate in IPOs that are of interest to them.

The rest of the paper is structured as follows. Section 2 develops the hypotheses. Sections 3 presents the data and the summary statistics. In Sections 4 and 5 we present our empirical analysis. Section 6 offers some robustness tests and section 7 concludes the paper.

\section{Hypotheses development}

A key difference between the bookbuilding and auction IPO mechanisms is the discretion available to underwriters in allocating shares. In contrast to auction IPOs, under the bookbuilding mechanism underwriters are allowed to exercise discretion in determining the share allocation rules. Proponents of the bookbuilding mechanism argue that this discretion allows underwriters to improve the efficiency and attain the objectives of the offering. One of the objectives of the offering, as cited by investment banks, is the preferential allocation of shares to individuals/institutions who are long term investors. This practice is commonly known as the pitchbook view of bookbuilding (Nimalendran et al., 2007). Consistent with 
this view, in their analysis of bookbuilding IPOs, Cornelli and Goldreich (2001) and Jenkinson and Jones (2004) report evidence of preferential allocation to investors who are perceived to be long-term holders of the stock. Also, in a survey of institutional investors, Jenkinson and Jones (2009) show that investors believe that their chance of receiving allocations improve if they are perceived as long-term investors.

The IPO listing process involves repeated interaction between underwriters and investors interested in subscribing to the IPOs. Existing research suggests that this setting coupled with the allocation discretion available to bookbuilding underwriters allows them to develop a sustained relation with a network of IPO investors. By rewarding the investors (through greater allocation of underpriced shares) and/or threatening them (with exclusion from the network), underwriters can influence investors' behaviour to achieve the objectives of the offering. Thus, unlike in auction mechanism, underwriters in bookbuilding can discourage investors from flipping by threatening them with exclusions from future share allocations. Given that underwriters in auction mechanism do not have allocation discretion and consequently no power in penalizing flippers (Degeorge et al., 2010), our first main hypothesis is:

$\mathbf{H}_{\mathbf{1}}$ : IPO investors flip less in bookbuilding than in auction IPOs.

Based on the findings in the IPO literature we further develop $\mathrm{H}_{1}$ three subhypotheses that centre on the allocation discretion and reputation of the underwriters, the strength of the offering and the investing behaviour of the investors.

High reputation (top-tier) underwriters not only manage the top IPOs and raise the most proceeds, they also have a broader network of investors than less reputed underwriters (Wang and Yung, 2011). Moreover, the top-tier underwriters have more established relationships with their IPO investors, which they can use to successfully manage even low 
quality offerings. Hence, if allocation discretion assists underwriter in discouraging investors from flipping immediately, then this relation should be more pronounced in IPOs managed by high reputation underwriters. This leads to our first sub-hypothesis which argues that:

$\mathbf{H}_{\mathbf{1} \mathbf{a}}$ : For IPOs managed by high reputation underwriters, investors flip less under the bookbuilding mechanism in comparison to auction IPOs.

Further, if underwriters in bookbuilding mechanism do indeed discourage investors from flipping shares, then this should be more prominent in weaker offerings where flipping is a bigger concern. Degeorge et al. (2010) find that investors in auction IPOs are equally likely to flip in both cold and hot IPOs and suggest that this is due to the underwriters' inability to control allocations. This leads to our second sub-hypothesis which argues that:

$\mathbf{H}_{\mathbf{1 b}}$ : In IPOs where the demand is weak, investors flip less in bookbuilding than in auction IPOs.

The underwriters' network of investors is likely to include both frequent and nonfrequent investors. Benveniste and Spindt (1989) show that allocation priority is given to an underwriter's frequent investors as compensation for information revelation. Hence, if repeated interaction between underwriter and investors leads to reduced flipping, then this effect should be more pronounced with frequent investors. This leads to our final subhypothesis where we suggest that:

$\mathbf{H}_{1 \mathbf{c}}$ : Frequent investors in bookbuilding IPOs should flip less than frequent investors in auction IPOs.

Finally, if bookbuilding underwriters are able to allocate shares to long-term investors, then these investors should not only flip less in the immediate aftermarket, but should also hold their shares for a longer period of time. In other words, investors in 
bookbuilding IPOs should hold on to their allocation for a longer period of time compared to investors in auction IPOs. This leads to our second main hypothesis that:

$\mathbf{H}_{2}$ : Investors in IPOs retain their allocation for longer periods under bookbuilding in comparison to auction mechanism. ${ }^{6}$

\section{Data and summary statistics}

Based on data availability our sample of FII trades begins in 2004. To capture the impact of the change in rules governing the method of IPO flotation we restrict our sample period to the end of 2006. The list of IPOs during the sample period was obtained from the BSE/NSE website. In total 188 IPOs were issued during this period. We excluded 41 fixedprice offerings because FIIs rarely subscribe to fixed price IPOs. Also 13 large privatization IPOs were excluded because of their size and the nature of the deals. Finally, a further 21 IPOs were excluded because of missing data. Our final sample consists of 103 IPOs which includes 45 bookbuilding and 58 auction IPOs listed on the Bombay Stock Exchange (BSE) and/or National Stock Exchange (NSE) between 2004 and 2006. The data on firm (assets and age) and offer characteristics (proceeds, shares offered and underwriters) were hand collected from the offer documents. Data on demand, bids and first day closing stock price were obtained from the BSE/NSE website. Return on the BSE Sensex index is used to calculate the market-adjusted underpricing.

The data on FII trades was obtained from the SEBI-endorsed NSDL FPI Monitor database. $^{7}$ This is a publicly available database that monitors and reports all FII trades from the beginning of January 2003. The database contains several fields, including the FII registration number, scrip name and ISIN code, transaction date, transaction type, transaction

\footnotetext{
${ }^{6}$ In our empirical analysis, we examine long term holdings by IPO mechanism for both frequent and nonfrequent investors.

${ }^{7}$ https://www.fpi.nsdl.co.in/web/Default.aspx
} 
rate and transaction value (in INRs). The field "transaction type" helps to identify whether a trade is a buy or sell and whether it is a primary or secondary market trade. A total of 3,009 primary trades for our sample of 103 IPOs were found. We use the data from these trades to determine IPO allocations to FII. Since every trade is assigned to a particular FII registration number, we then track trades by the registration number to determine flipping by FII.

We compare the FII allocation data obtained from NSDL FPI Monitor database with overall IPO allocation data that is publicly available for a large number of our IPOs. ${ }^{8}$ These publicly available data sources provide information on share allocation to the different investor categories, including allocation to FII. We found data for 93 of the 103 IPOs and the data from these two sources is almost identical ensuring reliability of our data.

We use the market share of underwriters to classify them as high/low reputation underwriters and assign the proceeds raised on a pro rata basis to all the lead managers in the IPO. A total of 30 underwriters manage the 103 sample IPOs, 21 of them were involved in bookbuilding and 28 in auction IPOs. A majority of these IPOs (85 out of the 103) were managed by either one or two underwriters. Following Bubna and Prabhala (2011), we classify an underwriter as high reputation if it ranks in the top five in the year of offering. We find that the sets of high reputation underwriters are almost identical in the two regimes. Unsurprisingly, these underwriters not only raise the most proceeds but they also manage the majority of the IPOs. Therefore, our classification yields exactly the same outcome if we use the number of offerings instead of the proceeds of the IPOs. ${ }^{9}$

\section{[Insert Table 1 here]}

\footnotetext{
${ }^{8}$ We gather this allocation data from BSE/NSE website as well as from other websites, such as chittorgarh.com, which is considered the premium IPO portal in India.

${ }^{9}$ Alternatively, we also look at the total proceeds raised in our three-year sample period to classify underwriters and arrive at an almost identical classification as obtained from the yearly data.
} 
Table 1 reports summary statistics related to firm and offer characteristics (Panel A The key features of allocation and flipping for the full sample, bookbuilding IPOs, and auction IPOs are reported in Panel B. Panel A shows that bookbuilding IPOs do not differ significantly from auction IPOs in terms of firm and offer characteristics. This suggests that although the sample period witnessed a change in regulatory system, there was no significant change in the characteristics of the IPO firms. The demand multiple and the number of institutional bids appear to be slightly lower in auction IPOs which can be attributed to bidder exit (as described in Bubna and Prabhala, 2011). Panel B (Table 1) shows that FIIs receive about 52 percent of the institutional allocation, which translates to an allocation of about 25 percent of the total offering. We also find that the allocation to FII is similar across the two regimes. The average size of allocation in the median overall IPO is about 136 thousand shares, and we do not find any significant difference in allocation between bookbuilding and auction IPOs.

For the overall sample (column 1), FII flip about 43 percent of the allocated shares in the first three days of trading. In unreported results we find that average flipping is 45 percent in the first seven days and 47 percent in first month of listing. Thus, investors who wish to flip their IPO allocations appear to do so in the first few days of listing. The percentage of flipping by FII in Indian IPOs is higher than the weighted average of about 26 percent reported for institutional investors in US IPOs in Aggarwal (2003).

The estimates in Table 1 show a significant difference in flipping between bookbuilding and auction IPOs. Flipping in the median bookbuilding IPO is 40 percent in the first three days of trading compared to 52 percent in the median auction IPO. Thus, the aggregate summary statistics, consistent with our first hypothesis $\left(\mathrm{H}_{1}\right)$, show that bookbuilding investors, on average, appear to flip less than auction investors. 
In summary, the three key observations from the summary statistics are: (i) both bookbuilding and auction IPOs have similar firm and offer characteristics; (ii) investor demand and overall allocation across the two mechanisms are similar; and (iii) flipping is significantly lower in bookbuilding than in auction IPOs.

\section{Investor flipping in bookbuilding versus auction IPOs}

Table 2 presents a comparative (univariate) analysis of shares allocated and flipped based for full-sample (column 1), bookbuilding (column 2), and auction (column 3) IPOs. Given that IPO investors are likely to flip their shares if they receive only a small allocation, perhaps due to rationing caused by high demand (Ellis, 2006), we split the sample into terciles based on shares allocated as a percentage of allocation to FIIs. ${ }^{10}$.

The estimates show that there is a significant difference in the allocation and flipping of shares across the terciles. An investor receives about 0.1 percent of total FII allocation in the lowest and approximately 2 percent in the middle tercile. The average investor in the top tercile receives about 11 percent of the allocation which translates to, on average, a sizeable 2.75 percent of the total shares on offer. ${ }^{11}$ The allocations are similar in both bookbuilding and auction IPOs. However, there is no systematic pattern between flipping and allocation across the terciles. The average flipping is 36 percent in the first tercile, 45 percent in the second and 38 percent in the third tercile of the full-sample. In bookbuilding average flipping appears to be relatively stable across the terciles (insignificant F-statistic). However, it varies significantly in auction IPOs. In auction investors within the second tercile flip about 53 percent of their allocations while it is only 42 percent in both the first and the third terciles.

\footnotetext{
${ }^{10}$ Individual allocations are placed in to three categories based on the fraction of shares allocated relative to the total shares offered in the IPO. We also create terciles using alternative approaches - see Section 7.2 for further discussion.

${ }^{11}$ As discussed earlier, FIIs receive about 50 percent of the allocation in the institutional investor category. The institutional investor category, in turn, is allocated about 50 percent of the total shares on offer.
} 
The difference in median flipping is even more dramatic - close to zero in the first and 61 percent in the second. More importantly, consistent with the evidence from summary statistics the difference in flipping between bookbuilding and auction IPOs is statistically significant. Further, although the difference is significant in all three terciles the difference is highest (21 percent) in the second tercile. Since the investors in the top tercile receive larger allocation (11 percent on average), even a small proportion of flipping of shares allocated to them is likely to have a much higher economic implication. Overall, the evidence from univariate analysis of flipping provides support to our first hypothesis $\left(\mathrm{H}_{1}\right)$ that investors flip less in bookbuilding than in auction IPOs.

\section{[Insert Table 2 here]}

Next we compare the compare the level of flipping in multivariate regression framework (in Equation 1 below) where the possible implications of other factors are controlled for.

$$
F l_{i}=\alpha+\beta_{1} \text { Mechanism }_{i}+\sum_{j=1}^{N} \gamma_{j} X_{i, j}+\varepsilon
$$

Where, the dependent variable $\left(F l_{i}\right)$ is the proportion of shares flipped by $F F I_{i}$ as a percentage of their allocation within the first three days of listing. The variable of interest is the mechanism dummy that takes the value of 1 for bookbuilding and 0 for auction IPOs. The vector $\left(X_{i, j}\right)$ represents control variables (market condition, underwriter reputation, and IPO proceeds) that are known to affect flipping. Since we are interested in investors' behaviour in weaker IPOs we also include a cold dummy variable which takes the value of 1 if underpricing is 10 percent or less and zero otherwise. ${ }^{12}$ All variables are defined in Appendix

\footnotetext{
${ }^{12}$ We use the 10 percent cut-off to consider cold and cool IPOs (Ellis, 2006). We re-run our analysis using alternative definitions of cold IPOs. See the discussion on alternative specifications in Section 6.2.
} 
A. The estimates are controlled for industry fixed effects ${ }^{13}$ and the results are presented in Table 3.

The estimates for the full-sample are given in Specification (1). Specifications (2) (4) show the results for each of the three IPO allocation terciles. The statistically significant negative coefficient of mechanism dummy (at $1 \%$ level) supports our first hypothesis $\left(\mathrm{H}_{1}\right)$ that IPO investors flip less in bookbuilding than in auction IPOs. Investors in bookbuilding flip approximately 8 percent less than in auction IPOs. Further, this result also holds for the second and third allocation terciles (significant at the $1 \%$ level). Although the coefficient on the mechanism dummy is higher in the second tercile (15.8\% in comparison to $6.5 \%)$, investors in the top tercile receive, on average, almost twice the number of shares than investors in the second tercile. Thus, although the size of the coefficients are different, the economic significance of the difference in flipping across the two mechanisms for the second and third terciles is similar. The mechanism dummy is insignificant in the bottom tercile, but as this group receives a very small allocation, it is possible this means that their flipping behaviour is similar under both methods of IPO flotation.

Among the control variables, for the full sample market condition is significantly positively related to flipping, although significant only for the top tercile when we consider the three groups. Underwriter reputation, on the other hand, is significantly negatively related to flipping, for the overall sample and the top allocation tercile. In fact, for the top tercile (specification 4), underwriters' reputation appears to be economically more significant than the selling mechanism. Investors who receive allocation in the top tercile are likely to flip about 11 percent less in IPOs that are managed by high reputation underwriters. Flipping is also significantly negatively related to the offer size in all specifications. The negative

\footnotetext{
${ }^{13}$ We group IPO firms into 11 industry sectors: consumer discretionary, consumer staples, energy, healthcare, industrials, financials, information technology, utilities, materials and telecommunication services.
} 
coefficient of cold IPO dummy is significant for the overall sample and weakly significant for the second tercile.

\section{[Insert Table 3 here]}

\subsection{Underwriter reputation and investor demand}

To test hypotheses $\left(\mathrm{H}_{1 \mathrm{a}}\right)$ and $\left(\mathrm{H}_{1 \mathrm{~b}}\right)$ two interaction terms are introduced in equation (1). To estimate the joint effect of underwriters and the IPO selling methods an interaction term between mechanism and underwriter reputation (Mechanism $\times$ Reputation) is included. Also to examine if investors flip weaker IPOs less in bookbuilding than in auction, an interaction between mechanism and cold IPOs (Mechanism $\times$ Cold) is added. The results are presented in specifications (5) - (8) of Table 3. The coefficients of interaction between mechanism and reputation are negative and significant for the full sample and the top two allocation terciles. This provides support for our first sub-hypothesis $\left(\mathrm{H}_{1 \mathrm{a}}\right)$ as investors flip less in bookbuilding if the IPOs are managed by high reputation underwriters. Given we find that the leading underwriters are the same across the two regimes, the results confirm that investors flipping behaviour is significantly affected by the discretionary allocation power of the underwriters. Further, the estimate in specification (8) suggests that investors in the top tercile flip approximately 15 percent less in bookbuilding IPOs if they are managed by leading underwriters.

The negative and significant coefficients of interaction between IPO mechanism and cold IPO (overall and in the bottom two terciles) suggests that in bookbuilding IPOs investors flip less in weak IPOs than in their comparable auction IPOs. This is consistent with the prediction of hypothesis $\mathrm{H}_{\mathrm{b}}$ that in weak IPOs investors flip less in bookbuilding than in auction. 
Overall, the results in Table 3 suggest that bookbuilding IPOs have considerably less flipping by investors in comparison to auction IPOs and difference is more prominent in IPOs where the demand is weak and that are managed by high reputation underwriters.

\subsection{Frequent and non-frequent investors}

For the reasons described earlier, $\mathrm{H}_{1 \mathrm{c}}$ posits that 'frequent IPO investors flip less in bookbuilding than in auction IPOs'. To test this hypothesis, we compare flipping between frequent and non-frequent FII. As in Bubna and Prabhala (2011) the tests are performed at the fund family level as data to track individual bidders across IPOs is not available. We define frequent investors as those belonging to a fund family that has subscribed at least 10 IPOs in either of the flotation regimes. Table 4 (Panel A) shows that the sample of 3,009 individual IPO bidders belong to 398 fund families. 304 fund families participate in bookbuilding and 243 in auction IPOs. Although several funds participate regularly in Indian IPOs a large number of fund families seem to be infrequent investors. 187 fund families have invested only on one or two IPOs and 162 fund families have participated on three to nine IPOs. Only 49 funds invested in 10 or more IPOs.

A significant number of bidders who participate in bookbuilding exit in the auction era. Only 149 out of the 304 bookbuilding fund families invest in auction IPOs. However, bidder exit is primarily in the non-frequent investor category. While only 47 of the 154 fund families who invest in one or two bookbuilding IPOs invest again in auction IPOs, all of the 44 fund families that invest in 10 or more bookbuilding IPOs not only participate in auction IPOs, but participate in them frequently. Thus, frequent bidders in the bookbuilding IPOs continue to participate frequently in the auction regime as well. In bookbuilding IPOs, the median fund family participates in 9 IPOs while the $75^{\text {th }}$ percentile bids in 18 IPOs; in 
auction IPOs, the median $\left(75^{\text {th }}\right.$ percentile) family participates in 15 (28) IPOs. ${ }^{14}$ For the purpose of our analysis, we classify frequent investors as those that belong to families that bid in at least 10 IPOs in either of the selling regimes. By employing this categorization, we have a set of frequent investors that are almost identical in both the selling regimes. ${ }^{15}$

\section{[Insert Table 4 here]}

Panel B (Table 4) provides a univariate analysis of flipping by frequent and nonfrequent investors. The estimates show that most of the bids by frequent investors receive an allocation in the top tercile. For instance, within the top tercile, 50 percent (819) of frequent investors receive an allocation, but it is only about 10 percent (144) in the cases of nonfrequent investors. Frequent investors flip significantly more of their allocation than nonfrequent investors (48\% vs. 31\%). This difference in flipping between frequent and nonfrequent investors is 19 percent in bookbuilding IPOs and about 11 percent in auction IPOs. However the estimates also show that both frequent and non-frequent investors flip less in bookbuilding than in auction IPOs. Consistent with hypothesis $\mathrm{H} 1_{c}$, frequent investors flip about 8 percent less in bookbuilding than in auction IPOs. Similarly, non-frequent investors flip about $16 \%$ less in bookbuilding IPOs than in auction IPOs. Therefore, the univariate results suggest that the difference in flipping that we observe between bookbuilding and auction mechanisms is consistent for both frequent and non-frequent IPO investors.

Panel $\mathrm{C}$ in Table 4 shows that both frequent and non-frequent investors flip less in the top two terciles of the allocation for both bookbuilding and auction IPOs. The median frequent investor in the top (middle) tercile in bookbuilding flips 17 (34) percent less than the

\footnotetext{
${ }^{14}$ Our figures are different from those of Bubna and Prabhala (2011), as we use a much larger sample than theirs (45 vs. 25$)$.

${ }^{15}$ There are five frequent fund families that are new in auction IPOs. For robustness purposes we re-run all our analysis by excluding these family funds. Our results remain qualitatively similar. Also see the section on robustness tests (Section 9), where we discuss alternative specifications of frequent investors.
} 
median investor in auction IPOs. Given that the median frequent investor in the top tercile receives about 6 percent of total FII allocation, the difference in flipping between the two selling mechanism is economically significant. As for the non-frequent investors, although the median investor in the second tercile holds on to their entire allocation, the median investor in the auction mechanism flips about $28 \%$ of their allocation.

We further examine the flipping behaviour of frequent and non-frequent investors in a multivariate framework based on equation (1) which is estimated separately for the two categories of investors. We also modify equation (1) to further examine hypothesis $\mathrm{H} 1_{\mathrm{a}}$ (underwriter reputation) and $\mathrm{H} 1_{\mathrm{b}}$ (weak IPOs) separately for the two investor categories. The results are reported in Table $5 .^{16,17}$

The negative and significant coefficients of 'mechanism' in specifications (1) - (3) suggest that the frequent investors flip less in bookbuilding than in auction IPOs. This is consistent with the predictions of hypothesis $\left(\mathrm{H}_{1 \mathrm{c}}\right)$. This evidence holds for the top two terciles as well. Underwriter reputation is significantly negatively related to flipping for frequent investors, for the overall sample and the top allocation tercile. However, in overall terms, there is no evidence to suggest that frequent investors flip less in weak IPOs. In specifications (4) - (6), we add the two previously discussed interaction terms: mechanism and underwriter reputation (Mechanism $\times$ Reputation) and mechanism and cold IPOs $($ Mechanism $\times$ Cold $)$. For the top two terciles, frequent investors in bookbuilding IPOs appear to flip less in weak IPOs and IPOs that are managed by high reputation underwriters. As indicated by the coefficient of the interaction variable, under bookbuilding frequent

\footnotetext{
${ }^{16}$ In unreported results, we repeat the analysis presented in Table 3 by also including the frequent investor dummy variable. We find that the frequent investor variable is positive and significant not only for the overall sample, but also for the top two allocation terciles.

17 To conserve space, we only report results for the overall sample and the top two quartiles. As discussed before, the bottom tercile is relatively less important as the median investor in this tercile receives only 0.1 percent of the total FII allocation.
} 
investors flip 46 percent less if the IPOs are managed by leading underwriters in the bookbuilding regime (specification 5) and approximately16 percent less in the top tercile (where due to the size of the allocation the economic effect is only marginally weaker).

\section{[Insert Table 5 here]}

In specifications (7) - (12), we repeat the analysis for non-frequent investors. The estimates show a significant negative relation for the overall sample and the $2^{\text {nd }}$ tercile indicating that non-frequent investors flip less in bookbuilding than in auction IPOs. The average non-frequent investor flips just over nine percent less in bookbuilding. However, average investors in the $2^{\text {nd }}$ tercile flip nearly 20 percent less in bookbuilding IPOs than in auction IPOs. Thus, the analysis in Table 5 shows that both frequent and non-frequent investors flip significantly less in bookbuilding than in auction IPOs. It is noteworthy that none of the interaction terms in specifications (9) - (12) are significant for non-frequent investors. Overall, the effects of the discretionary power of the bookbuilding mechanism which allows the underwriters to target and preferentially allocate shares to long-term holders is also supported by the evidence that even the non-frequent investors flip less in bookbuilding. ${ }^{18}$

\section{Long-term holdings}

This section examines hypothesis $2\left(\mathbf{H}_{2}\right)$ examining if subscribers of IPOs retain their allocation for longer term in bookbuilding than in auction IPOs. If bookbuilding underwriters are able to allocate shares to long-term investors then they should dispose less of their allocation over a longer period than the investors in auction IPOs. We track each of the 3,009 individual allocations for six months after the IPO listing. ${ }^{19}$ Table 6 (Panel A) provides a

\footnotetext{
${ }^{18}$ In unreported results, we re-run all the analysis using flipping data for the first seven days as well as for the first month of listing. All our results are qualitatively similar.

${ }^{19}$ The results, available on request, are qualitatively similar when one year holding period is used.
} 
univariate analysis of shares sold by IPO mechanism, relative to the allocation they had received, at the end of six months of listing. The estimates show that a significantly lower proportion of shares being sold within the first six months under bookbuilding than in auction IPOs. This result holds for both frequent and non-frequent IPO investors. The overall difference in the percentage of shares sold between bookbuilding and auction IPOs is approximately 9 percent at the end of six months; with the difference of 14 percent for nonfrequent investors and 6 percent for frequent investors.

In Panel B we present the statistics by allocation terciles. For frequent investors, the difference in the fraction of shares sold across the two regimes narrows over time and also becomes statistically less significant. For non-frequent investors, on the other hand, the difference in shares sold across the two regimes remains both economically as well as statistically significant even at the end of the six months of listing. The median non-frequent investor in the second allocation tercile holds on to their entire allocation, compared to the median non-frequent investor in the auction regime who disposes of about 76 percent of their allocation.

\section{[Insert Table 6 here]}

To assess the implications of IPO mechanism on long-term holdings after controlling for the effects of other factors equation (2) is estimated as follows:

$$
\operatorname{Sold}_{i}=\alpha+\beta_{1} \text { Mechanism }_{i}+\sum_{j=1}^{N} \gamma_{j} X_{i, j}+\varepsilon
$$

In Equation (2), the dependent variable $\left(\operatorname{Sold}_{i}\right)$ is the percentage of shares sold by investor $i$ within the first six months relative to the allocation received. The vector of control 
variables $\left(X_{i, j}\right)$ includes stock return ${ }^{20}$, underwriters' reputation, IPO proceeds, and a dummy variable representing weak IPOs. All variables are defined in Appendix A. In the estimate we control for industry fixed effects and the results are presented in Table 7.

Estimates in specifications (1) - (3), show that the IPO mechanism does not appear to affect the long-term selling behaviour of the frequent investors. However, when we interact mechanism with underwriter reputation in the model (specifications 4 and 5), we find a significant negative relation with the IPO mechanism for the full sample as well as for midtercile. Similarly, when we interact the mechanism with the weak IPOs we find a significant negative relation. The results for non-frequent investors are reported in specifications (7) (12). The difference in post listing disposal based on the IPO mechanism is significant only in the case of the second tercile. However, none of the interaction terms are significant.

\section{[Insert Table 7 here]}

As an additional test of long-term holdings, we analyse investors holding their entire allocation until the end of six months from listing. We perform a probit regression analysis and present the results in Table 8, where the dependent variable takes the value of 1 if the investor holds on to his/her entire allocation for six months and 0 otherwise. All explanatory variables remain the same as in equation (2). In the case of frequent investors (specifications 1-3), the coefficients of mechanism dummy are statistically significant in all but one case (specification 3). Similarly, the coefficients of the interaction of mechanism dummy with underwriter reputation and weak IPOs (Mechanism $\times$ Reputation, and Mechanism $\times$ Cold) are generally significant. Consistent with our earlier evidence, estimates show that non-

\footnotetext{
${ }^{20}$ In addition to annualised return (as defined in Appendix A) we also use buy-and hold return, annualized returns based on the average daily returns for the first three, four and five months. The results, available on request, are qualitatively similar.
} 
frequent investors in the middle tercile are more likely to hold on to their entire allocation in bookbuilding IPOs than in auction IPOs (specification 8$).^{21}$

\section{[Insert Table 8 here]}

\section{Robustness tests}

\subsection{Excluding IPOs from the last six months of bookbuilding regime}

Our sample includes 13 IPOs that were issued in the last six months of bookbuilding regime. As the forthcoming change in regulation was in public domain, inclusion of these IPOs in the sample could introduce a downward bias in the estimates. An obvious concern is also with long-term analysis, as the six-month period for this sub-sample of IPOs would extend into the auction regime. Hence, we re-run all the analysis by excluding these 13 IPOs and the 564 IPO allocations associated with them. The results (available on request) show that overall flipping is about 5 percent higher (statistically significant) in these 13 bookbuilding IPO compared to the other 32 IPOs.

Further, there are a few interesting results in the multivariate regressions of the reduced sample. First, the magnitude of the coefficients of the mechanism dummy across all the specifications is markedly larger. For instance, in specification (4) in Table 3 the coefficient of mechanism is 0.065 , but it is 0.079 for the reduced sample. Second, for frequent investors, the coefficients of the mechanism dummy and its interaction with the reputation of the underwriters (Mechanism $\times$ Reputation) are also higher. Third, in the cases of long-term holdings of frequent investors, the coefficients of the mechanism dummy are also significant for the top two terciles. Finally, the coefficients of mechanism dummy in non-frequent investors' case are also markedly higher. Overall, these additional tests provide

\footnotetext{
${ }^{21}$ In unreported results, we re-run the analysis by using holdings of at least 50 percent and at least 75 percent of the initial allocation as the threshold. Our results remain qualitatively similar. Our results also hold when we use investors' holdings at the end of year of the listing.
} 
further support for the findings discussed earlier in the paper that that investors (particularly for frequent investors) in bookbuilding IPOs flip significantly less than investors in auction IPOs.

\subsection{Alternative specifications}

We investigate the robustness of all empirical results to variations in our specifications. First, instead of using the 10 percent first day return as the threshold to identify weak IPOs, we use (i) IPOs with negative returns, and (ii) IPOs with returns below the overall median return as alternative measures for weak IPOs. As in Bubna and Prabhala (2011), we also use the level of oversubscription (below and above median) to classify firms as weak IPOs. All our results remain qualitatively similar to these alternative specifications (the results are available from the authors on request).

Second, to classify the investors into frequent and non-frequent, we use several alternative specifications. Instead of using the cut-off of investing in 10 IPOs, we re-run all our analysis by defining frequent investors as those (i) who participate in at least 18 IPOs (the $75^{\text {th }}$ percentile for bookbuilding IPOs) in each of the selling regimes and (ii) a combined total of at least 38 IPOs in the two regimes (the $75^{\text {th }}$ percentile for the number of IPOs participated in by fund families in the two regimes - see Panel A, Table 4). Again, all our results remain qualitatively similar.

Finally, we also use alternative approaches to construct allocation terciles. We created terciles based on allocation separately for bookbuilding IPOs and auction IPOs; terciles based on the allocation of each individual IPO; terciles based on shares allocated as a percentage of total institutional quota; and terciles based on shares allocated as a percentage of total offering. All results are qualitatively similar across all the alternative specifications and are available from the authors on request. 


\section{Conclusion}

The discretion available to underwriters in the bookbuilding mechanism to control allocation has been a source of the debate on whether bookbuilding is superior to the auction method of bringing new issues to the market. Despite bookbuilding being a leading mechanism around the world, critics argue that the information extraction benefit of the bookbuilding can also be achieved through alternative mechanisms such as auctions, where potential for manipulation and abuse is less. However, studies in support of bookbuilding show that the most effective approach to incorporate non-bid information is to allow flexibility in pricing and allocation. The paper contributes to this debate and provides new evidence on the importance of discretion in bookbuilding by examining the flipping behaviour of FII across bookbuilding and auction IPOs in India.

In a quasi-natural experiment setting of the Indian market, the findings of the paper are consistent with the theoretical arguments often attached to bookbuilding that underwriters' flexibility in allocation should not only help them to avoid allocation to flippers, but also help develop long-term relationships with IPO investors. We find that both frequent as well as non-frequent investors flip significantly less in bookbuilding than in auction IPOs. Further, frequent investors, who are almost identical across the two selling regimes and receive the bulk of the allocation, appear to flip significantly less in IPOs managed by leading underwriters (who are also the same in the two mechanisms). They also flip less in weaker IPOs providing support to both underwriters and issuers. The evidence from the analysis of longer term holdings post IPO floatation show that a larger proportion of IPO subscribers hold on to their entire allocation at least for six months of listing in bookbuilding than in auction IPOs. 
Overall, our findings, as well as those presented in Bubna and Prabhala (2011), suggests that allocation discretion available to underwriters appears to benefit both issuers and underwriters. Taken together, the evidence suggests that the flexibility in allocation not only helps in improving the pre-market price discovery, but also in influencing the behaviour of the frequent investors as well as to incorporate soft non-bid information by preferentially allocating shares to long-term investors. 


\section{References}

Aggarwal R. Allocation of initial public offerings and flipping activity. Journal of Financial Economics 2003;68; 111-135

Benveniste LM, Spindt PA. How investment bankers determine the offer price and allocation of new issues. Journal of Financial Economics 1989;24; 343-361

Benveniste LM, Wilhelm WJ. A comparative analysis of IPO proceeds under alternative regulatory environments. Journal of Financial Economics 1990;28; 173-207

Bubna A, Prabhala NR. IPOs with and without Allocation Discretion: Empirical Evidence. Journal of Financial Intermediation 2011;20; 530-561

Cornelli F, Goldreich D. Bookbuilding and strategic allocation. Journal of Finance 2001;56; 23372369

Degeorge F, Derrien F, Womack K. Auctioned IPOs: The US Evidence. Journal of Financial Economics 2010;98; 177-194

Degeorge F, Derrien F, Womack KL. Analyst Hype in IPOs: Explaining the Popularity of Bookbuilding. Review of Financial Studies 2007;20; 1021-1058

Ellis K. Who trades IPOs? A close look at the first days of trading. Journal of Financial Economics $2006 ; 79 ; 339-363$

Jagannathan R, Jirnyi A, Sherman AG. Share auctions of initial public offerings: Global evidence. Journal of Financial Intermediation 2015;24; 283-311

Jenkinson T, Jones H. Bids and allocations in European IPO bookbuilding. Journal of Finance 2004;59; 2309-2338

Jenkinson T, Jones H. IPO pricing and allocation: a survey of the views of institutional investors. Review of Financial Studies 2009;22; 1477-1504

Krigman L, Shaw W, Womack K. The persistence of IPO mispricing and the predictive power of flipping. Journal of Finance 1999;54; 1015-1044

Kutsuna K, Smith R. Why does book building drive out auction methods of IPO issuance? Evidence from Japan. Review of Financial Studies 2004;17; 1129-1166

Loughran T, Ritter J. Why has IPO underpricing changed over time? Financial Management 2004;33; $5-37$

Lowry M, Officer M, Schwert G. The Variability of IPO Initial Returns. Journal of Finance 2010;65; $425-465$

Neupane S, Poshakwale S. Transparency in IPO Mechanism: Retail investors' participation, IPO pricing and returns. Journal of Banking and Finance 2012;36; 2064-2076

Nimalendran M, Ritter JR, Zhang D. Do today's trades affect tomorrow's IPO allocations? Journal of Financial Economics 2007;84; 87-109

Ritter JR. Equilibrium in the initial public offerings market. Annual Review of Financial Economics $2011 ; 3 ; 347-374$

Sherman AE. IPOs and long-term relationships: an advantage of book building. Review of Financial Studies 2000;13; 697-714 
Wang W, Yung C. IPO information aggregation and underwriter quality. Review of Finance 2011;15; 301 
Variable Name

Mechanism

Assets (INR Mill)

Age

Proceeds (INR Mill)

Shares offered (Mill)

Underwriter

underwriters

Market condition

Stock return

Total demand

(oversubscription)

No of Institutional Bids

Institutional Demand Multiple

Underpricing

Share allocated to FII as percent of total institutional quota

Average size of institutional The average number of shares allocated to FII allocation ('000)

Shares allocated as a percent of total FII allocation

Shares flipped as percent of allocation

Frequent FII Investors

Terciles of Allocation

Cold IPOs

\section{Definition} IPOs of shares offered. month before the offering (Mt-3). offered to institutional investors. the first day of trading. foreign institutional investors (FII). listing. total shares allocated to total FII investors.
A dummy variable that take the value of 1 for bookbuilding IPOs and 0 for auction

The book value of total assets at the time of IPO in INR millions.

Difference (in years) between a firm's IPO year and the founding year.

Gross proceeds of the offer calculated by multiplying the offer price by the number

Total number of shares offered in the IPO offering (in millions).

The binary variable which equals 1 for reputed/leading underwriters and 0 otherwise. Following Bubna and Prabhala (2011), we categorize underwriters as reputable who are ranked top 5 in the year of offering, and zero otherwise.

The weighted average of the buy-and-hold returns on the BSE Sensex index in the three months prior to the IPO issue opening date $t$; the weights being 3 for the month before the IPO date (Mt-1), 2 for the month before that (Mt-2), and 1 for the third

Annualized return based on the average daily stock returns for the first six months of listing, excluding the return on the first day of listing

multiple The ratio of total shares bid by all investors to the total number of shares offered.

Total number of bids submitted by institutional investors.

The ratio of total shares bid by the institutional investors to the total number of shares

The market adjusted first day returns. Market adjusted first day returns in the difference between raw first day return and market return, where the market return is the return on the BSE Sensex index over the same period. Raw first day return is the simple return calculated between the offer price and the closing price at the end of

The percentage of share reserved for institutional investors which is allocated to

The percentage of shares allocated to each individual investor relative to the total shares offered to all the FII investors in the IPO.

The percentage of shares allocated which is sold (flipped) in the first 3 days of

A dummy variable that takes the value of 1 for IPO investors who have invested in at least 15 IPOs either in bookbuilding or auction IPOs.

Terciles based on the percentage of shares allocated to FII investors relative to the

A dummy variable that takes the value of 1 for IPOs with underpricing of $10 \%$ or less and zero otherwise. 


\section{Table 1: Summary Statistics}

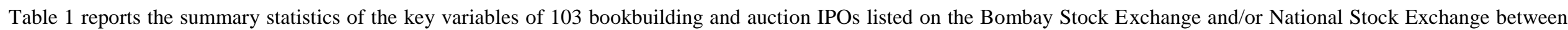

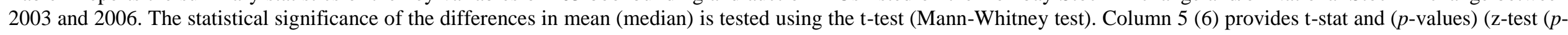
values)) for the difference in mean (median). Appendix A provides definitions of all the variables.

\begin{tabular}{|c|c|c|c|c|c|c|}
\hline & $\begin{array}{c}\text { Total } \\
\text { (1) }\end{array}$ & $\begin{array}{c}\text { Bookbuilding } \\
\text { (2) }\end{array}$ & $\begin{array}{c}\text { Auction } \\
\text { (3) }\end{array}$ & $\begin{array}{c}\text { Diff }(2-3) \\
(4)\end{array}$ & $\begin{array}{c}\text { t-stat ( } p \text {-value) } \\
(5)\end{array}$ & $\begin{array}{c}\text { z-test ( } p \text {-value) } \\
(6)\end{array}$ \\
\hline \multicolumn{7}{|l|}{ Panel A: Firm and offer characteristics } \\
\hline Assets (INR Million) & $5,730(1,800)$ & $6,664(1,895)$ & $5,005(1,766)$ & $1,658(129)$ & $0.732(0.466)$ & $0.246(0.806)$ \\
\hline Age & $15.24(12.81)$ & $15.82(12.00)$ & $14.79(12.87)$ & $1.034(-0.87)$ & $0.441(0.660)$ & $-0.532(0.594)$ \\
\hline Proceeds (INR Million) & $2,673(1,080)$ & $3,435(1,000)$ & $2,083(1,090)$ & $1,352(-90)$ & $1.266(0.208)$ & $-0.150(0.881)$ \\
\hline Shares Offered (Million) & $21.56(8.15)$ & $32.78(10.00)$ & $12.92(6.85)$ & $19.86(3.15)$ & $1.975(0.051)$ & $2.071(0.038)$ \\
\hline Underwriter Reputation & $0.68(1.00)$ & $0.72(1.00)$ & $0.66(1.00)$ & $0.06(0.00)$ & $0.661(0.510)$ & $0.663(0.507)$ \\
\hline Total Demand Multiple & $23.54(18.67)$ & $26.31(22.64)$ & $21.45(12.42)$ & $4.86(10.22)$ & $1.148(0.254)$ & $1.855(0.063)$ \\
\hline Number of Institutional Bids & $122(86)$ & $148(97)$ & $106(71)$ & $42(26)$ & $1.651(0.102)$ & $1,962(0.050)$ \\
\hline Institutional Demand Multiple & $25.77(18.43)$ & $23.31(18.76)$ & $27.63(17.44)$ & $-4.32(1.32)$ & $-0.787(0.433)$ & $0.185(0.854)$ \\
\hline Underpricing & $0.305(0.22)$ & $0.34(0.26)$ & $0.28(0.15)$ & $0.06(0.11)$ & $0.662(0.509)$ & $1.579(0.114)$ \\
\hline \multicolumn{7}{|l|}{ Panel B: Allocation \& Flipping - FIIs } \\
\hline Share allocated as a percent of total institutional quota & $0.52(0.53)$ & $0.50(0.50)$ & $0.54(0.54)$ & $-0.04(-0.04)$ & $-1.319(0.190)$ & $-1.021(0.307)$ \\
\hline Average size of allocation ('000) & $306(136)$ & $357(136)$ & $266(134)$ & $91(2)$ & $0.925(0.357)$ & $0.217(0.624)$ \\
\hline Average size of flipping - ('000) & $130(41)$ & $134(38)$ & $126(43)$ & $8(-5)$ & $0.119(0.902)$ & $0.497(0.481)$ \\
\hline Shares flipped as a percent of allocation & $0.43(0.45)$ & $0.38(0.40)$ & $0.47(0.52)$ & $-0.09(-0.12)$ & $-1.865(0.065)$ & $-4.276(0.033)$ \\
\hline Observations & 103 & 45 & 58 & & & \\
\hline
\end{tabular}




\section{Table 2: Flipping: Univariate Analysis}

Table 2 shows the univariate analysis of flipping in the first 3 days of listing for 3,009 IPO allocations to foreign institutional investors (FIIs) investors for a sample of 45 bookbuilding and 58 auction IPOs listed on the Bombay Stock Exchange and/or National Stock Exchange between 2004 and 2006 . We present statistics for three terciles of allocation based on the percentage of shares allocated to FIIs. The statistical significance of the differences in mean (median) is tested using the t-test (Mann-Whitney test). Column 5 (6) provides t-stat and ( $p$-values) (z-test ( $p$-values)) for the difference in mean (median). F-stat (p-value) is the test statistic (p-value) of Anova F-test to test for equality across the three allocation categories.

\begin{tabular}{|c|c|c|c|c|c|c|}
\hline & $\begin{array}{l}\text { Overall } \\
\text { (1) }\end{array}$ & $\begin{array}{c}\text { Bookbuilding } \\
\text { (2) }\end{array}$ & $\begin{array}{l}\text { Auction } \\
\text { (3) }\end{array}$ & $\begin{array}{c}\text { Diff }(2-3) \\
(4)\end{array}$ & $\begin{array}{c}\text { t-stat (p-value) } \\
(5)\end{array}$ & $\begin{array}{c}\text { z-test (p-value) } \\
(6)\end{array}$ \\
\hline \multicolumn{7}{|l|}{ Tercile $1(n=1,003)$} \\
\hline Shares allocated as percent of total FII allocation & $0.001(0.002)$ & $0.002(0.002)$ & $0.002(0.002)$ & $0.000(0.000)$ & $0.894(0.371)$ & $1.566(0.212)$ \\
\hline Shares flipped as percent of allocation & $0.36(0.00)$ & $0.33(0.00)$ & $0.42(0.00)$ & $-0.09(0.00)$ & $-2.908(0.003)$ & $-4.251(0.018)$ \\
\hline \multicolumn{7}{|l|}{ Tercile $2(n=1,013)$} \\
\hline Shares allocated as percent of total FII allocation & $0.02(0.03)$ & $0.02(0.03)$ & $0.02(0.03)$ & $0.00(0.00)$ & $1.432(0.285)$ & $3.248(0.068)$ \\
\hline Shares flipped as percent of allocation & $0.45(0.35)$ & $0.32(0.00)$ & $0.53(0.61)$ & $-0.21(-0.61)$ & $-6.948(0.000)$ & $-36.812(0.000)$ \\
\hline \multicolumn{7}{|l|}{ Tercile $3(n=993)$} \\
\hline Shares allocated as percent of total FII allocation & $0.11(0.06)$ & $0.11(0.06)$ & $0.10(0.06)$ & $0.001(0.002)$ & $0.481(0.630)$ & $3.236(0.072)$ \\
\hline Shares flipped as percent of allocation & $0.38(0.17)$ & $0.34(0.02)$ & $0.42(0.24)$ & $-0.08(-0.53)$ & $-4.690(0.000)$ & $-8.715(0.000)$ \\
\hline Shares allocated percent - F-stat ( $p$-value) & $665.38(0.000)$ & $351.21(0.000)$ & $280.72(0.000)$ & & & \\
\hline Share flipped percent - F-stat ( $p$-value) & $11.68(0.000)$ & $0.06(0.943)$ & $11.05(0.000)$ & & & \\
\hline Observations & 3,009 & 1,403 & 1,606 & & & \\
\hline
\end{tabular}




\section{Table 3: IPO Investor Flipping: OLS regression analysis}

Table 3 reports the estimates of the OLS regression analysis of IPO investor flipping in the first 3 days of listing for 3,009 IPO allocations to foreign institutional investors (FIIs) investors for a sample of 45 bookbuilding and 58 auction IPOs listed on the Bombay Stock Exchange and/or National Stock Exchange between 2004 and 2006. The dependent variable in all the specifications is the fraction of shares sold in the first 3 days of listing. Appendix A provides definitions of all the variables. All tests use White heteroskedasticity robust standard errors. The p-values are in brackets. ***, ** and * indicate statistically significant at 1 percent, 5 percent and 10 percent respectively.

\begin{tabular}{|c|c|c|c|c|c|c|c|c|}
\hline & $\begin{array}{l}\text { Overall } \\
\text { (1) }\end{array}$ & $\begin{array}{l}\text { Tercile } 1 \\
\text { (2) }\end{array}$ & $\begin{array}{l}\text { Tercile } 2 \\
\text { (3) }\end{array}$ & $\begin{array}{l}\text { Tercile } 3 \\
\text { (4) }\end{array}$ & $\begin{array}{l}\text { Overall } \\
(5)\end{array}$ & $\begin{array}{l}\text { Tercile } 1 \\
\text { (6) }\end{array}$ & $\begin{array}{l}\text { Tercile } 2 \\
\text { (7) }\end{array}$ & $\begin{array}{c}\text { Tercile } 3 \\
(8)\end{array}$ \\
\hline Mechanism & $\begin{array}{c}-0.080 * * * \\
(-5.09)\end{array}$ & $\begin{array}{l}-0.011 \\
(-0.32)\end{array}$ & $\begin{array}{c}-0.158 * * * \\
(-5.22)\end{array}$ & $\begin{array}{c}-0.065 * * * \\
(-2.86)\end{array}$ & $\begin{array}{c}0.128 * * \\
(2.04)\end{array}$ & $\begin{array}{c}0.200 \\
(0.80)\end{array}$ & $\begin{array}{c}0.270^{*} \\
(1.73)\end{array}$ & $\begin{array}{l}0.070 \\
(0.93)\end{array}$ \\
\hline Market Condition & $\begin{array}{c}0.632 * * * \\
\quad(2.63)\end{array}$ & $\begin{array}{l}0.045 \\
(0.07)\end{array}$ & $\begin{array}{l}0.688 \\
(1.43)\end{array}$ & $\begin{array}{c}0.668 * * \\
(2.21)\end{array}$ & $\begin{array}{c}0.588 * * \\
(2.43)\end{array}$ & $\begin{array}{l}0.002 \\
(0.00)\end{array}$ & $\begin{array}{l}0.674 \\
(1.42)\end{array}$ & $\begin{array}{c}0.602 * * \\
(1.98)\end{array}$ \\
\hline Reputation & $\begin{array}{c}-0.065 * * \\
(-2.03)\end{array}$ & $\begin{array}{l}-0.085 \\
(-0.65)\end{array}$ & $\begin{array}{l}0.009 \\
(0.13)\end{array}$ & $\begin{array}{c}-0.109 * * * \\
(-3.15)\end{array}$ & $\begin{array}{l}0.002 \\
(0.05)\end{array}$ & $\begin{array}{l}0.026 \\
(0.14)\end{array}$ & $\begin{array}{l}0.117 \\
(1.48)\end{array}$ & $\begin{array}{l}-0.058 \\
(-1.25)\end{array}$ \\
\hline Proceeds (log) & $\begin{array}{c}-0.048 * * * \\
(-5.96)\end{array}$ & $\begin{array}{c}-0.072 * * * \\
(-4.20)\end{array}$ & $\begin{array}{c}-0.083 * * * \\
(-5.04)\end{array}$ & $\begin{array}{c}-0.051 * * * \\
(-3.79)\end{array}$ & $\begin{array}{c}-0.051 * * * \\
(-6.05)\end{array}$ & $\begin{array}{c}-0.080 * * * \\
(-4.50)\end{array}$ & $\begin{array}{c}-0.086 * * * \\
(-5.12)\end{array}$ & $\begin{array}{c}-0.052 * * * \\
(-3.79)\end{array}$ \\
\hline Cold & $\begin{array}{c}-0.058 * * * \\
(-2.70)\end{array}$ & $\begin{array}{l}-0.037 \\
(-0.66)\end{array}$ & $\begin{array}{c}-0.063 * \\
(-1.67)\end{array}$ & $\begin{array}{l}-0.023 \\
(-0.70)\end{array}$ & $\begin{array}{l}-0.019 \\
(-0.72)\end{array}$ & $\begin{array}{l}0.078 \\
(1.02)\end{array}$ & $\begin{array}{l}0.019 \\
(0.40)\end{array}$ & $\begin{array}{l}-0.011 \\
(-0.28)\end{array}$ \\
\hline Mechanism $\times$ Reputation & & & & & $\begin{array}{c}-0.201 * * * \\
(-3.09)\end{array}$ & $\begin{array}{l}-0.180 \\
(-0.72)\end{array}$ & $\begin{array}{c}-0.402 * * \\
(-2.52)\end{array}$ & $\begin{array}{c}-0.147 * * \\
(-2.19)\end{array}$ \\
\hline Mechanism $\times$ Cold & & & & & $\begin{array}{c}-0.110 * * * \\
(-2.71)\end{array}$ & $\begin{array}{c}-0.248 * * \\
(-2.30)\end{array}$ & $\begin{array}{c}-0.204 * * * \\
(-2.77)\end{array}$ & $\begin{array}{l}-0.049 \\
(-0.83)\end{array}$ \\
\hline Industry FE & Yes & Yes & Yes & Yes & Yes & Yes & Yes & Yes \\
\hline Constant & $\begin{array}{c}0.915^{* * * *} \\
(14.20) \\
\end{array}$ & $\begin{array}{c}1.174 * * * \\
(6.44) \\
\end{array}$ & $\begin{array}{c}1.158 * * * \\
(8.37) \\
\end{array}$ & $\begin{array}{c}0.912 * * * \\
(9.45) \\
\end{array}$ & $\begin{array}{c}0.861 * * * \\
(12.23) \\
\end{array}$ & $\begin{array}{c}1.120 * * * \\
(4.76) \\
\end{array}$ & $\begin{array}{c}1.073 * * * \\
(7.49) \\
\end{array}$ & $\begin{array}{c}0.874 * * * \\
(8.54) \\
\end{array}$ \\
\hline $\begin{array}{l}\text { Observations } \\
\text { Adjusted } R^{2}\end{array}$ & $\begin{array}{l}3,009 \\
0.058\end{array}$ & $\begin{array}{l}1,003 \\
0.054\end{array}$ & $\begin{array}{l}1,013 \\
0.096\end{array}$ & $\begin{array}{c}993 \\
0.062 \\
\end{array}$ & $\begin{array}{l}3,009 \\
0.062\end{array}$ & $\begin{array}{l}1,003 \\
0.057 \\
\end{array}$ & $\begin{array}{l}1,013 \\
0.106\end{array}$ & $\begin{array}{c}993 \\
0.064\end{array}$ \\
\hline
\end{tabular}


Table 4: Frequent and non-frequent investors: Univariate analysis

Table 4 reports the univariate statistics of flipping in the first 3 days of listing by frequent and non-frequent IPO investors. Panel A shows statistics of bidding by fund families in the 45 bookbuilding and 58 auction IPOs. Panel B compares flipping by frequent and non-frequent investors between bookbuilding and auction IPO investors while Panel C shows flipping by frequent and non-frequent investors in bookbuilding and auction IPOs for the three allocation terciles. The allocation terciles are based on the percentage of shares allocated to FIIs. The statistical significance of the differences in mean (median) is tested using the t-test (Mann-Whitney test).

Panel A: Fund family participation in IPOs

\begin{tabular}{|c|c|c|c|}
\hline & Total & Bookbuilding & Auction \\
\hline \multicolumn{4}{|l|}{ \# of fund families bidding in: } \\
\hline 1-2 IPOs & 187 & 154 & 132 \\
\hline 3-9 IPOs & 162 & 106 & 48 \\
\hline 10 or more IPOs & 49 & 44 & 49 \\
\hline Total & 398 & 304 & 243 \\
\hline \multicolumn{4}{|l|}{ \# of IPOs bids by fund families } \\
\hline $25^{\text {th }}$ Percentile & 5 & 4 & 4 \\
\hline Mean & 25 & 12 & 17 \\
\hline Median & 14 & 9 & 15 \\
\hline $75^{\text {th }}$ Percentile & 38 & 18 & 28 \\
\hline
\end{tabular}

Panel B: By mechanism and investors

\begin{tabular}{|c|c|c|c|c|c|c|c|c|}
\hline & \multicolumn{4}{|c|}{ Frequent Investors } & \multicolumn{4}{|c|}{ Non-Frequent Investors } \\
\hline & $\begin{array}{c}\text { Bookbuilding } \\
\text { (1) }\end{array}$ & $\begin{array}{l}\text { Auction } \\
(2) \\
\end{array}$ & $\begin{array}{c}\text { Diff (1-2) } \\
\text { (3) } \\
\end{array}$ & $\begin{array}{c}p \text {-values } \\
(4)\end{array}$ & $\begin{array}{c}\text { Bookbuilding } \\
\text { (5) }\end{array}$ & $\begin{array}{l}\text { Auction } \\
(6) \\
\end{array}$ & $\begin{array}{c}\text { Diff (5-6) } \\
(7) \\
\end{array}$ & $\begin{array}{c}p \text {-values } \\
(8)\end{array}$ \\
\hline \multicolumn{9}{|c|}{ Shares flipped as percent of allocation } \\
\hline Tercile 1 & $0.51(0.50)$ & $0.57(0.94)$ & $-0.06(-0.44)$ & $0.295(0.322)$ & $0.26(0.00)$ & $0.37(0.00)$ & $-0.11(0.00)$ & $0.001(0.009)$ \\
\hline Tercile 2 & $0.45(0.34)$ & $0.57(0.68)$ & $-0.12(-0.34)$ & $0.004(0.005)$ & $0.21(0.00)$ & $0.46(0.28)$ & $-0.25(-0.28)$ & $0.000(0.000)$ \\
\hline Tercile 3 & $0.38(0.16)$ & $0.45(0.33)$ & $-0.07(-0.17)$ & $0.006(0.002)$ & $0.19(0.00)$ & $0.25(0.00)$ & $-0.06(0.00)$ & $0.245(0.022)$ \\
\hline Observations & 661 & 988 & & & 742 & 618 & & \\
\hline
\end{tabular}


Panel C: By mechanism, investors and allocation terciles

\begin{tabular}{|c|c|c|c|c|c|c|}
\hline & $\begin{array}{l}\text { Overall } \\
\text { (1) }\end{array}$ & $\begin{array}{l}\text { Frequent } \\
\text { Investors } \\
\text { (2) }\end{array}$ & $\begin{array}{l}\text { Non-Frequent Investors } \\
\text { (3) }\end{array}$ & $\begin{array}{c}\text { Diff 2-3) } \\
(4)\end{array}$ & $\begin{array}{c}\text { t-stat ( } p \text {-value }) \\
(5)\end{array}$ & $\begin{array}{c}\text { z-test (p-value) } \\
\text { (6) }\end{array}$ \\
\hline Shares flipped as percent of allocation - Overall & $0.40(0.05)$ & $0.48(0.48)$ & $0.31(0.00)$ & $0.17(0.48)$ & $10.456(0.000)$ & $111.54(0.000)$ \\
\hline Shares flipped as percent of allocation - Bookbuilding & $0.33(0.00)$ & $0.43(0.27)$ & $0.24(0.00)$ & $0.19(0.27)$ & $6.897(0.000)$ & $54.08(0.000)$ \\
\hline Shares flipped as percent of allocation - Auction & $0.46(0.36)$ & $0.51(0.52)$ & $0.40(0.00)$ & $0.11(0.55)$ & $5.216(0.000)$ & $26.31(0.000)$ \\
\hline Diff (Bookbuilding - Auction) & $-0.13(-0.36)$ & $-0.08(-0.25)$ & $-0.16(0.00)$ & & & \\
\hline t-stat ( $p$-value) & $-8.144(0.000)$ & $-3.422(0.000)$ & $-5.675(0.000)$ & & & \\
\hline z-test ( $p$-value) & $53.64(0.000)$ & $9.886(0.001)$ & $18.583(0.000)$ & & & \\
\hline Observations & 3,009 & 1,649 & 1,360 & & & \\
\hline \multicolumn{7}{|l|}{ \# of allocations by terciles } \\
\hline First & & 250 & 763 & & & \\
\hline Second & & 580 & 453 & & & \\
\hline Third & & 819 & 144 & & & \\
\hline
\end{tabular}




\section{Table 5: Frequent and non-frequent investors: OLS regression analysis}

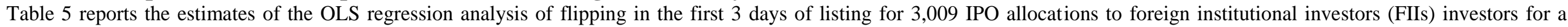

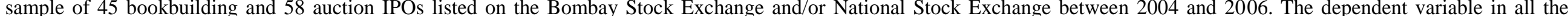

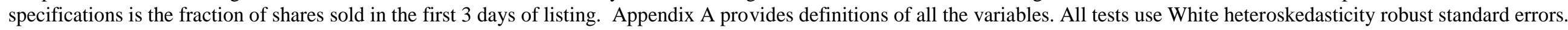
The p-values are in brackets. $* * *, * *$ and $*$ indicate statistically significant at 1 percent, 5 percent and 10 percent respectively.

\begin{tabular}{|c|c|c|c|c|c|c|c|c|c|c|c|c|}
\hline & \multicolumn{6}{|c|}{ Frequent Investors } & \multicolumn{6}{|c|}{ Non-Frequent Investors } \\
\hline & $\begin{array}{l}\text { Overall } \\
\text { (1) }\end{array}$ & $\begin{array}{l}\text { Tercile } 2 \\
\text { (2) }\end{array}$ & $\begin{array}{l}\text { Tercile } 3 \\
\text { (3) }\end{array}$ & $\begin{array}{l}\text { Overall } \\
\text { (4) }\end{array}$ & $\begin{array}{l}\text { Tercile } 2 \\
(5)\end{array}$ & $\begin{array}{l}\text { Tercile } 3 \\
\text { (6) }\end{array}$ & $\begin{array}{l}\text { Overall } \\
\text { (7) }\end{array}$ & $\begin{array}{l}\text { Tercile } 2 \\
\text { (8) }\end{array}$ & $\begin{array}{l}\text { Tercile } 3 \\
\text { (9) }\end{array}$ & $\begin{array}{c}\text { Overall } \\
(10)\end{array}$ & $\begin{array}{l}\text { Tercile } 2 \\
\text { (11) }\end{array}$ & $\begin{array}{c}\text { Tercile } 3 \\
\text { (12) }\end{array}$ \\
\hline Mechanism & $\begin{array}{c}-0.068 * * * \\
(-2.93)\end{array}$ & $\begin{array}{c}-0.088^{*} \\
(-1.94)\end{array}$ & $\begin{array}{c}-0.068 * * \\
(-2.15)\end{array}$ & $\begin{array}{c}0.146^{* *} * \\
(2.15)\end{array}$ & $\begin{array}{c}0.401 * * * \\
(2.65)\end{array}$ & $\begin{array}{l}0.084 \\
(1.09)\end{array}$ & $\begin{array}{c}-0.091 * * * \\
(-3.07)\end{array}$ & $\begin{array}{c}-0.197 * * * \\
(-3.88)\end{array}$ & $\begin{array}{l}-0.031 \\
(-0.46)\end{array}$ & $\begin{array}{l}0.129 \\
(0.61)\end{array}$ & $\begin{array}{c}-0.592 * * * \\
(-3.75)\end{array}$ & $\begin{array}{l}0.315 \\
(1.14)\end{array}$ \\
\hline Market Condition & $\begin{array}{c}0.679 * * \\
(2.44)\end{array}$ & $\begin{array}{l}0.656 \\
(1.16)\end{array}$ & $\begin{array}{c}0.781 * * \\
(2.32)\end{array}$ & $\begin{array}{c}0.608 * * \\
(2.17)\end{array}$ & $\begin{array}{l}0.662 \\
(1.22)\end{array}$ & $\begin{array}{c}0.683 * * \\
(2.01)\end{array}$ & $\begin{array}{l}0.388 \\
(0.80)\end{array}$ & $\begin{array}{l}1.128 \\
(1.23)\end{array}$ & $\begin{array}{l}0.180 \\
(0.28)\end{array}$ & $\begin{array}{l}0.379 \\
(0.79)\end{array}$ & $\begin{array}{l}1.211 \\
(1.30)\end{array}$ & $\begin{array}{l}0.248 \\
(0.39)\end{array}$ \\
\hline Reputation & $\begin{array}{c}-0.075^{* *} \\
(-2.11)\end{array}$ & $\begin{array}{l}-0.070 \\
(-0.79)\end{array}$ & $\begin{array}{c}-0.094 * * \\
(-2.32)\end{array}$ & $\begin{array}{l}-0.003 \\
(-0.07)\end{array}$ & $\begin{array}{l}0.075 \\
(0.73)\end{array}$ & $\begin{array}{l}-0.037 \\
(-0.74)\end{array}$ & $\begin{array}{l}-0.005 \\
(-0.06)\end{array}$ & $\begin{array}{l}0.049 \\
(0.40)\end{array}$ & $\begin{array}{l}-0.181 \\
(-1.43)\end{array}$ & $\begin{array}{l}0.034 \\
(0.38)\end{array}$ & $\begin{array}{l}0.032 \\
(0.23)\end{array}$ & $\begin{array}{l}-0.098 \\
(-0.71)\end{array}$ \\
\hline Proceeds (log) & $\begin{array}{l}-0.009 \\
(-0.79)\end{array}$ & $\begin{array}{l}-0.026 \\
(-1.08)\end{array}$ & $\begin{array}{c}-0.038 * * \\
(-2.35)\end{array}$ & $\begin{array}{l}-0.013 \\
(-1.12)\end{array}$ & $\begin{array}{l}-0.034 \\
(-1.41)\end{array}$ & $\begin{array}{c}-0.041 * * \\
(-2.50)\end{array}$ & $\begin{array}{c}-0.050 * * * \\
(-3.58)\end{array}$ & $\begin{array}{c}-0.097 * * * \\
(-3.65)\end{array}$ & $\begin{array}{c}-0.049 * \\
(-1.68)\end{array}$ & $\begin{array}{c}-0.049 * * * \\
(-3.38)\end{array}$ & $\begin{array}{c}-0.101 * * * \\
(-3.68)\end{array}$ & $\begin{array}{l}-0.050 * \\
(-1.70)\end{array}$ \\
\hline Cold IPOs & $\begin{array}{l}-0.042 \\
(-1.63)\end{array}$ & $\begin{array}{l}-0.017 \\
(-0.35)\end{array}$ & $\begin{array}{l}-0.014 \\
(-0.39)\end{array}$ & $\begin{array}{l}0.003 \\
(0.10)\end{array}$ & $\begin{array}{l}0.064 \\
(1.18)\end{array}$ & $\begin{array}{l}0.010 \\
(0.23)\end{array}$ & $\begin{array}{c}-0.163 * * * \\
(-4.37)\end{array}$ & $\begin{array}{c}-0.149 * * \\
(-2.49)\end{array}$ & $\begin{array}{l}-0.105 \\
(-1.44)\end{array}$ & $\begin{array}{c}-0.156 * * * \\
(-3.17)\end{array}$ & $\begin{array}{l}-0.111 \\
(-1.26)\end{array}$ & $\begin{array}{l}-0.119 \\
(-1.32)\end{array}$ \\
\hline Mechanism $\times$ Reputation & & & & $\begin{array}{c}-0.203 * * * \\
(-2.87)\end{array}$ & $\begin{array}{c}-0.464 * * * \\
(-2.94)\end{array}$ & $\begin{array}{c}-0.158 * * \\
(-2.23)\end{array}$ & & & & $\begin{array}{l}-0.223 \\
(-1.06)\end{array}$ & $\begin{array}{l}0.424 \\
(1.01)\end{array}$ & $\begin{array}{l}-0.373 \\
(-1.37)\end{array}$ \\
\hline Mechanism $\times$ Cold & & & & $\begin{array}{c}-0.131 * * * \\
(-2.67)\end{array}$ & $\begin{array}{c}-0.254 * * * \\
(-2.73)\end{array}$ & $\begin{array}{c}-0.075^{* *} \\
(-2.02)\end{array}$ & & & & $\begin{array}{l}-0.012 \\
(-0.16)\end{array}$ & $\begin{array}{l}-0.101 \\
(-0.83)\end{array}$ & $\begin{array}{l}0.012 \\
(0.07)\end{array}$ \\
\hline Industry Fixed Effects & Yes & Yes & Yes & Yes & Yes & Yes & Yes & Yes & Yes & Yes & Yes & Yes \\
\hline Constant & $\begin{array}{c}0.654 * * * \\
(7.57) \\
\end{array}$ & $\begin{array}{c}0.843 * * * \\
(4.57) \\
\end{array}$ & $\begin{array}{c}0.816^{* * * *} \\
(7.19) \\
\end{array}$ & $\begin{array}{c}0.609 * * * \\
(6.68) \\
\end{array}$ & $\begin{array}{c}0.758 * * * \\
(4.00) \\
\end{array}$ & $\begin{array}{c}0.785^{* * * *} \\
(6.60) \\
\end{array}$ & $\begin{array}{c}0.829 * * * \\
(5.93)\end{array}$ & $\begin{array}{c}1.067 * * * \\
(4.36)\end{array}$ & $\begin{array}{c}0.864 * * * \\
(3.43)\end{array}$ & $\begin{array}{c}0.781 * * * \\
(5.31) \\
\end{array}$ & $\begin{array}{c}1.120 * * * \\
(4.34)\end{array}$ & $\begin{array}{c}0.795 * * * \\
(3.03)\end{array}$ \\
\hline $\begin{array}{l}\text { Observations } \\
\text { Adjusted } R^{2}\end{array}$ & $\begin{array}{l}1649 \\
0.042\end{array}$ & $\begin{array}{c}580 \\
0.047\end{array}$ & $\begin{array}{c}819 \\
0.048\end{array}$ & $\begin{array}{l}1649 \\
0.049\end{array}$ & $\begin{array}{c}580 \\
0.065\end{array}$ & $\begin{array}{c}819 \\
0.052\end{array}$ & $\begin{array}{l}1360 \\
0.058\end{array}$ & $\begin{array}{c}453 \\
0.126\end{array}$ & $\begin{array}{c}144 \\
0.088\end{array}$ & $\begin{array}{c}1360 \\
0.058\end{array}$ & $\begin{array}{c}453 \\
0.125\end{array}$ & $\begin{array}{c}144 \\
0.090\end{array}$ \\
\hline
\end{tabular}




\section{Table 6: Long term IPO holdings: Univariate analysis}

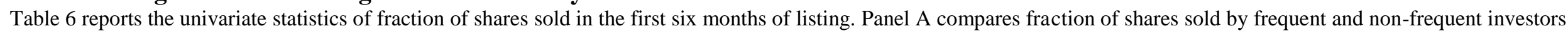
between bookbuilding and auction IPO investors while Panel C shows fraction of shares sold by frequent and non-frequent investors in bookbuilding and auction IPOs for the three allocation terciles. The allocation terciles are based on the percentage of shares allocated to FIIs. The statistical significance of the differences in mean (median) is tested using the t-test (Mann-Whitney test).

Panel A: By mechanism and investors

\begin{tabular}{|c|c|c|c|c|c|c|}
\hline & $\begin{array}{l}\text { Overall } \\
\text { (1) }\end{array}$ & $\begin{array}{l}\text { Frequent Investors } \\
\text { (2) }\end{array}$ & $\begin{array}{l}\text { Non-Frequent Investors } \\
\text { (3) }\end{array}$ & $\begin{array}{c}\text { Diff }(2-3) \\
(4)\end{array}$ & $\begin{array}{c}\text { t-stat ( } p \text {-value }) \\
(5)\end{array}$ & $\begin{array}{c}\text { z-test ( } p \text {-value) } \\
(6)\end{array}$ \\
\hline Shares flipped as percent of allocation - Overall & $0.47(0.38)$ & $0.54(0.57)$ & $0.39(0.00)$ & $0.15(0.57)$ & $7.702(0.000)$ & $68.64(0.000)$ \\
\hline Shares flipped as percent of allocation - Bookbuilding & $0.42(0.15)$ & $0.50(0.52)$ & $0.32(0.00)$ & $0.18(0.52)$ & $6.189(0.000)$ & $37.01(0.000)$ \\
\hline Shares flipped as percent of allocation - Auction & $0.51(0.57)$ & $0.56(0.69)$ & $0.46(0.00)$ & $0.11(0.69)$ & $5.237(0.000)$ & $19.56(0.000)$ \\
\hline Diff (Bookbuilding - Auction) & $-0.09(-0.42)$ & $-0.06(-0.17)$ & $-0.14(0.00)$ & & & \\
\hline t-stat ( $p$-value) & $-5.25(0.000)$ & $-2.46(0.014)$ & $-3.274(0.000)$ & & & \\
\hline z-test ( $p$-value) & $20.84(0.000)$ & $4.077(0.035)$ & $6.914(0.000)$ & & & \\
\hline Observations & & 1,649 & 1,360 & & & \\
\hline
\end{tabular}

Panel B: By mechanism, investors and allocation terciles

\begin{tabular}{|c|c|c|c|c|c|c|c|c|}
\hline & \multicolumn{4}{|c|}{ Frequent Investors } & \multicolumn{4}{|c|}{ Non-Frequent Investors } \\
\hline & $\begin{array}{c}\text { Bookbuilding } \\
\text { (1) }\end{array}$ & $\begin{array}{l}\text { Auction } \\
(2)\end{array}$ & $\begin{array}{c}\text { Diff (1-2) } \\
\text { (3) }\end{array}$ & $\begin{array}{c}p \text {-values } \\
(4)\end{array}$ & $\begin{array}{c}\text { Bookbuilding } \\
\text { (5) }\end{array}$ & $\begin{array}{l}\text { Auction } \\
(6)\end{array}$ & $\begin{array}{c}\text { Diff (5-6) } \\
(7) \\
\end{array}$ & $\begin{array}{c}p \text {-values } \\
(8)\end{array}$ \\
\hline \multicolumn{9}{|c|}{ Shares flipped as percent of allocation } \\
\hline Tercile 1 & $0.83(1.00)$ & $0.66(1.00)$ & $0.17(0.00)$ & $0.311(0.881)$ & $0.41(0.00)$ & $0.42(0.00)$ & $-0.01(0.00)$ & $0.799(0.895)$ \\
\hline Tercile 2 & $0.55(0.59)$ & $0.62(0.82)$ & $-0.07(-0.23)$ & $0.069(0.212)$ & $0.29(0.00)$ & $0.52(0.76)$ & $-0.23(-0.76)$ & $0.000(0.000)$ \\
\hline Tercile 3 & $0.46(0.38)$ & $0.51(0.50)$ & $-0.05(-0.12)$ & $0.145(0.154)$ & $0.32(0.00)$ & $0.32(0.00)$ & $0.00(0.00)$ & $0.999(0.154)$ \\
\hline Observations & 661 & 988 & & & 742 & 618 & & \\
\hline
\end{tabular}




\section{Table 7: Long term holdings: OLS regression analysis}

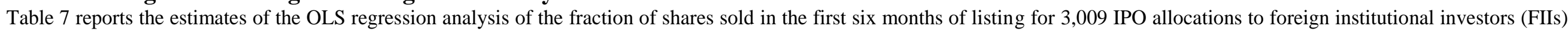

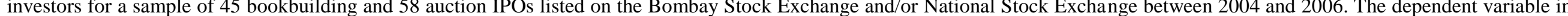

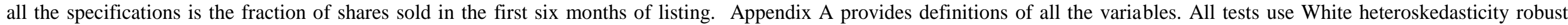
standard errors. The p-values are in brackets. $* * *, * *$ and $*$ indicate statistically significant at 1 percent, 5 percent and 10 percent respectively.

\begin{tabular}{|c|c|c|c|c|c|c|c|c|c|c|c|c|}
\hline & \multicolumn{6}{|c|}{ Frequent Investors } & \multicolumn{6}{|c|}{ Non-Frequent Investors } \\
\hline & $\begin{array}{l}\text { Overall } \\
\text { (1) }\end{array}$ & $\begin{array}{c}\text { Tercile } 2 \\
\text { (2) }\end{array}$ & $\begin{array}{c}\text { Tercile } 3 \\
(3)\end{array}$ & $\begin{array}{c}\text { Overall } \\
(4)\end{array}$ & $\begin{array}{c}\text { Tercile } 2 \\
(5)\end{array}$ & $\begin{array}{c}\text { Tercile } 3 \\
(6)\end{array}$ & $\begin{array}{l}\text { Overall } \\
(7)\end{array}$ & $\begin{array}{c}\text { Tercile } 2 \\
(8)\end{array}$ & $\begin{array}{c}\text { Tercile } 3 \\
(9)\end{array}$ & $\begin{array}{c}\text { Overall } \\
(10)\end{array}$ & $\begin{array}{c}\text { Tercile } 2 \\
\text { (11) }\end{array}$ & $\begin{array}{c}\text { Tercile } 3 \\
\text { (12) }\end{array}$ \\
\hline Mechanism & $\begin{array}{l}-0.014 \\
(-0.41)\end{array}$ & $\begin{array}{l}-0.068 \\
(-1.51)\end{array}$ & $\begin{array}{l}-0.039 \\
(-1.16)\end{array}$ & $\begin{array}{c}0.200 * * * \\
(2.83)\end{array}$ & $\begin{array}{c}0.506 * * * \\
(3.68)\end{array}$ & $\begin{array}{l}0.067 \\
(0.86)\end{array}$ & $\begin{array}{l}-0.007 \\
(-0.21)\end{array}$ & $\begin{array}{c}-0.185^{* * * *} \\
(-3.38)\end{array}$ & $\begin{array}{l}0.032 \\
(0.43)\end{array}$ & $\begin{array}{l}0.115 \\
(0.45)\end{array}$ & $\begin{array}{c}-0.721 * * * \\
(-4.60)\end{array}$ & $\begin{array}{l}0.268 \\
(0.87)\end{array}$ \\
\hline Stock Return & $\begin{array}{l}0.009 \\
(0.40)\end{array}$ & $\begin{array}{l}0.030 \\
(1.07)\end{array}$ & $\begin{array}{c}-0.063 * * * \\
(-3.10)\end{array}$ & $\begin{array}{l}0.015 \\
(0.61)\end{array}$ & $\begin{array}{l}0.044 \\
(1.55)\end{array}$ & $\begin{array}{c}-0.060 * * * \\
(-2.97)\end{array}$ & $\begin{array}{c}0.076 * * * \\
(3.67)\end{array}$ & $\begin{array}{c}0.103 * * * \\
(2.76)\end{array}$ & $\begin{array}{c}-0.103 * * * \\
(-2.87)\end{array}$ & $\begin{array}{c}0.073 * * * \\
(3.51)\end{array}$ & $\begin{array}{c}0.089 * * \\
(2.32)\end{array}$ & $\begin{array}{c}-0.103 * * * \\
(-2.76)\end{array}$ \\
\hline Reputation & $\begin{array}{c}-0.095 * * \\
(-2.37)\end{array}$ & $\begin{array}{l}-0.083 \\
(-0.91)\end{array}$ & $\begin{array}{c}-0.081 * \\
(-1.95)\end{array}$ & $\begin{array}{l}-0.030 \\
(-0.59)\end{array}$ & $\begin{array}{l}0.076 \\
(0.71)\end{array}$ & $\begin{array}{l}-0.043 \\
(-0.86)\end{array}$ & $\begin{array}{l}-0.113 \\
(-1.34)\end{array}$ & $\begin{array}{l}0.003 \\
(0.02)\end{array}$ & $\begin{array}{l}-0.190 \\
(-1.39)\end{array}$ & $\begin{array}{l}-0.080 \\
(-0.88)\end{array}$ & $\begin{array}{l}-0.002 \\
(-0.01)\end{array}$ & $\begin{array}{l}-0.123 \\
(-0.82)\end{array}$ \\
\hline Proceeds (log) & $\begin{array}{l}0.026 \\
(1.10)\end{array}$ & $\begin{array}{l}-0.025 \\
(-1.00)\end{array}$ & $\begin{array}{c}-0.036 * * \\
(-2.12)\end{array}$ & $\begin{array}{l}0.020 \\
(0.85)\end{array}$ & $\begin{array}{l}-0.033 \\
(-1.33)\end{array}$ & $\begin{array}{c}-0.038 * * \\
(-2.24)\end{array}$ & $\begin{array}{c}-0.063^{* * *} \\
(-4.11)\end{array}$ & $\begin{array}{c}-0.096^{* * *} \\
(-3.40)\end{array}$ & $\begin{array}{c}-0.071 * * \\
(-2.27)\end{array}$ & $\begin{array}{c}-0.067 * * * \\
(-4.17)\end{array}$ & $\begin{array}{c}-0.106 * * * \\
(-3.62)\end{array}$ & $\begin{array}{c}-0.070 * * \\
(-2.21)\end{array}$ \\
\hline Cold IPOs & $\begin{array}{c}-0.117 * * * \\
(-3.76)\end{array}$ & $\begin{array}{c}-0.088 * \\
(-1.90)\end{array}$ & $\begin{array}{l}-0.024 \\
(-0.70)\end{array}$ & $\begin{array}{c}-0.055^{*} \\
(-1.65)\end{array}$ & $\begin{array}{l}0.004 \\
(0.08)\end{array}$ & $\begin{array}{l}-0.004 \\
(-0.10)\end{array}$ & $\begin{array}{c}-0.217 * * * \\
(-5.82)\end{array}$ & $\begin{array}{c}-0.176^{* * *} \\
(-3.02)\end{array}$ & $\begin{array}{l}-0.077 \\
(-1.09)\end{array}$ & $\begin{array}{c}-0.172 * * * \\
(-3.39)\end{array}$ & $\begin{array}{l}-0.088 \\
(-1.01)\end{array}$ & $\begin{array}{l}-0.110 \\
(-1.19)\end{array}$ \\
\hline Mechanism $\times$ Reputation & & & & $\begin{array}{c}-0.187 * * \\
(-2.54)\end{array}$ & $\begin{array}{c}-0.543 * * * \\
(-3.86)\end{array}$ & $\begin{array}{l}-0.108 \\
(-1.30)\end{array}$ & & & & $\begin{array}{l}-0.105 \\
(-0.41)\end{array}$ & $\begin{array}{l}0.597 \\
(1.36)\end{array}$ & $\begin{array}{l}-0.276 \\
(-0.88)\end{array}$ \\
\hline Mechanism $\times$ Cold & & & & $\begin{array}{c}-0.176^{* * *} \\
(-3.28)\end{array}$ & $\begin{array}{c}-0.304 * * * \\
(-3.23)\end{array}$ & $\begin{array}{l}-0.055 \\
(-0.82)\end{array}$ & & & & $\begin{array}{l}-0.114 \\
(-1.47)\end{array}$ & $\begin{array}{c}-0.228^{*} \\
(-1.82)\end{array}$ & $\begin{array}{l}0.070 \\
(0.40)\end{array}$ \\
\hline Industry Fixed Effects & Yes & Yes & Yes & Yes & Yes & Yes & Yes & Yes & Yes & Yes & Yes & Yes \\
\hline Constant & $\begin{array}{c}0.545^{* * * *} \\
(3.33)\end{array}$ & $\begin{array}{c}0.968 * * * \\
(5.11)\end{array}$ & $\begin{array}{c}0.903 * * * \\
(7.63)\end{array}$ & $\begin{array}{c}0.609 * * * \\
(6.68)\end{array}$ & $\begin{array}{c}0.758 * * * \\
(4.00)\end{array}$ & $\begin{array}{c}0.785 * * * \\
(6.60)\end{array}$ & $\begin{array}{c}1.162 * * * \\
(7.94)\end{array}$ & $\begin{array}{c}1.360 * * * \\
(5.24)\end{array}$ & $\begin{array}{c}1.071 * * * \\
(4.13)\end{array}$ & $\begin{array}{c}1.156 * * * \\
(7.54)\end{array}$ & $\begin{array}{c}1.450 * * * \\
(5.41)\end{array}$ & $\begin{array}{c}1.012 * * * \\
(3.73)\end{array}$ \\
\hline Observations & 1649 & 580 & 819 & 1649 & 580 & 819 & 1360 & 453 & 144 & 1360 & 453 & 144 \\
\hline Adjusted $R^{2}$ & 0.016 & 0.054 & 0.060 & 0.049 & 0.065 & 0.052 & 0.054 & 0.128 & 0.096 & 0.054 & 0.133 & 0.093 \\
\hline
\end{tabular}


Table 8: Long term holdings: Probit regression analysis

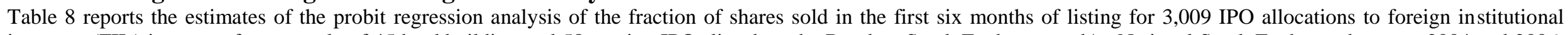

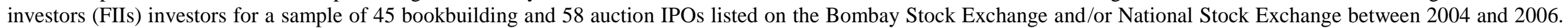
The dependent variable in all the specifications takes the value of 1 if investors hold their entire allocation at the end of six months and zero otherwise. Appendix A provides

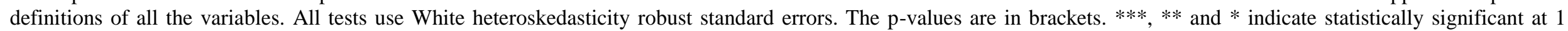
percent, 5 percent and 10 percent respectively.

\begin{tabular}{|c|c|c|c|c|c|c|c|c|c|c|c|c|}
\hline & \multicolumn{6}{|c|}{ Frequent Investors } & \multicolumn{6}{|c|}{ Non-Frequent Investors } \\
\hline & $\begin{array}{l}\text { Overall } \\
\text { (1) }\end{array}$ & $\begin{array}{l}\text { Tercile } 2 \\
\text { (2) }\end{array}$ & $\begin{array}{c}\text { Tercile } 3 \\
\text { (3) }\end{array}$ & $\begin{array}{l}\text { Overall } \\
\text { (4) }\end{array}$ & $\begin{array}{c}\text { Tercile } 2 \\
(5)\end{array}$ & $\begin{array}{c}\text { Tercile } 3 \\
\text { (6) }\end{array}$ & $\begin{array}{c}\text { Overall } \\
\text { (7) }\end{array}$ & $\begin{array}{c}\text { Tercile } 2 \\
(8)\end{array}$ & $\begin{array}{c}\text { Tercile } 3 \\
\text { (9) }\end{array}$ & $\begin{array}{l}\text { Overall } \\
\text { (10) }\end{array}$ & $\begin{array}{c}\text { Tercile } 2 \\
\text { (11) }\end{array}$ & $\begin{array}{c}\text { Tercile } 3 \\
\text { (12) }\end{array}$ \\
\hline Mechanism & $\begin{array}{c}0.142 * * \\
(2.14)\end{array}$ & $\begin{array}{c}0.277 * * \\
(2.28)\end{array}$ & $\begin{array}{l}0.064 \\
(0.68)\end{array}$ & $\begin{array}{c}-1.004 * * * \\
(-4.60)\end{array}$ & $\begin{array}{c}-5.435 * * * \\
(-16.54)\end{array}$ & $\begin{array}{c}-0.841 * * * \\
(-3.40)\end{array}$ & $\begin{array}{l}0.116 \\
(1.55)\end{array}$ & $\begin{array}{c}0.442 * * * \\
(3.42)\end{array}$ & $\begin{array}{l}0.246 \\
(1.13)\end{array}$ & $\begin{array}{l}-0.302 \\
(-0.46)\end{array}$ & $\begin{array}{c}4.986 * * * \\
(11.23)\end{array}$ & $\begin{array}{l}-0.221 \\
(-0.24)\end{array}$ \\
\hline Stock Return & $\begin{array}{c}-0.282 * * * \\
(-3.15)\end{array}$ & $\begin{array}{l}0.076 \\
(0.39)\end{array}$ & $\begin{array}{c}-0.399 * * * \\
(-3.41)\end{array}$ & $\begin{array}{c}-0.324 * * * \\
(-3.75)\end{array}$ & $\begin{array}{l}0.115 \\
(0.57)\end{array}$ & $\begin{array}{c}-0.461 * * * \\
(-4.02)\end{array}$ & $\begin{array}{l}0.011 \\
(0.10)\end{array}$ & $\begin{array}{l}0.183 \\
(0.90)\end{array}$ & $\begin{array}{c}-0.719 * * * \\
(-2.66)\end{array}$ & $\begin{array}{l}0.020 \\
(0.19)\end{array}$ & $\begin{array}{l}0.261 \\
(1.26)\end{array}$ & $\begin{array}{c}-0.742 * * * \\
(-2.73)\end{array}$ \\
\hline Reputation & $\begin{array}{l}-0.071 \\
(-0.70)\end{array}$ & $\begin{array}{l}-0.275 \\
(-1.21)\end{array}$ & $\begin{array}{l}0.010 \\
(0.08)\end{array}$ & $\begin{array}{c}-0.401 * * * \\
(-3.43)\end{array}$ & $\begin{array}{c}-0.695 * * * \\
(-2.81)\end{array}$ & $\begin{array}{c}-0.296 * * \\
(-2.02)\end{array}$ & $\begin{array}{l}0.208 \\
(0.89)\end{array}$ & $\begin{array}{l}-0.198 \\
(-0.57)\end{array}$ & $\begin{array}{l}0.413 \\
(1.02)\end{array}$ & $\begin{array}{l}0.070 \\
(0.27)\end{array}$ & $\begin{array}{l}-0.275 \\
(-0.75)\end{array}$ & $\begin{array}{l}0.254 \\
(0.55)\end{array}$ \\
\hline Proceeds (log) & $\begin{array}{c}-0.094 * * * \\
(-2.78)\end{array}$ & $\begin{array}{l}0.010 \\
(0.15)\end{array}$ & $\begin{array}{c}-0.177 * * * \\
(-3.33)\end{array}$ & $\begin{array}{c}-0.093 * * * \\
(-2.71)\end{array}$ & $\begin{array}{l}0.026 \\
(0.38)\end{array}$ & $\begin{array}{c}-0.185 * * * \\
(-3.48)\end{array}$ & $\begin{array}{c}0.095 * * \\
(2.48)\end{array}$ & $\begin{array}{c}0.170 * * \\
(2.44)\end{array}$ & $\begin{array}{l}-0.093 \\
(-0.94)\end{array}$ & $\begin{array}{c}0.110 * * * \\
(2.79)\end{array}$ & $\begin{array}{c}0.200 * * * \\
(2.81)\end{array}$ & $\begin{array}{l}-0.102 \\
(-1.01)\end{array}$ \\
\hline Cold IPOs & $\begin{array}{l}-0.110 \\
(-1.23)\end{array}$ & $\begin{array}{l}0.096 \\
(0.55)\end{array}$ & $\begin{array}{c}-0.225^{*} \\
(-1.86)\end{array}$ & $\begin{array}{c}-0.262 * * \\
(-2.49)\end{array}$ & $\begin{array}{l}0.002 \\
(0.01)\end{array}$ & $\begin{array}{c}-0.328 * * \\
(-2.31)\end{array}$ & $\begin{array}{c}0.410 * * * \\
(3.19)\end{array}$ & $\begin{array}{c}0.565 * * * \\
(2.77)\end{array}$ & $\begin{array}{l}-0.082 \\
(-0.29)\end{array}$ & $\begin{array}{l}0.224 \\
(1.48)\end{array}$ & $\begin{array}{l}0.368 \\
(1.57)\end{array}$ & $\begin{array}{l}0.002 \\
(0.00)\end{array}$ \\
\hline Mechanism $\times$ Reputation & & & & $\begin{array}{c}1.172 * * * \\
(5.24)\end{array}$ & $\begin{array}{c}5.720 * * * \\
(18.19)\end{array}$ & $\begin{array}{c}1.006 * * * \\
(3.84)\end{array}$ & & & & $\begin{array}{l}0.351 \\
(0.53)\end{array}$ & $\begin{array}{l}-0.687 \\
(-1.10)\end{array}$ & $\begin{array}{l}0.571 \\
(0.62)\end{array}$ \\
\hline Mechanism $\times$ Cold & & & & $\begin{array}{c}0.372 * * \\
(2.51)\end{array}$ & $\begin{array}{l}0.449 \\
(1.51)\end{array}$ & $\begin{array}{l}0.229 \\
(1.15)\end{array}$ & & & & $\begin{array}{c}0.506^{* *} \\
(2.29)\end{array}$ & $\begin{array}{c}0.658^{*} \\
(1.94)\end{array}$ & $\begin{array}{l}-0.219 \\
(-0.46)\end{array}$ \\
\hline Industry Fixed Effects & Yes & Yes & Yes & Yes & Yes & Yes & Yes & Yes & Yes & Yes & Yes & Yes \\
\hline Constant & $\begin{array}{l}0.358 \\
(1.37)\end{array}$ & $\begin{array}{l}-0.560 \\
(-1.01) \\
\end{array}$ & $\begin{array}{c}1.035 * * * \\
(2.71)\end{array}$ & $\begin{array}{c}0.688 * * \\
(2.53)\end{array}$ & $\begin{array}{l}-0.300 \\
(-0.53) \\
\end{array}$ & $\begin{array}{c}1.389 * * * \\
(3.53)\end{array}$ & $\begin{array}{c}-1.060 * * * \\
(-2.60)\end{array}$ & $\begin{array}{c}-1.632 * * \\
(-2.35)\end{array}$ & $\begin{array}{l}0.649 \\
(0.77)\end{array}$ & $\begin{array}{c}-1.017 * * \\
(-2.38)\end{array}$ & $\begin{array}{c}-1.806 * * \\
(-2.52)\end{array}$ & $\begin{array}{l}0.828 \\
(0.96)\end{array}$ \\
\hline Observations & 1649 & 580 & 819 & 1649 & 580 & 819 & 1360 & 453 & 144 & 1360 & 453 & 144 \\
\hline Adjusted $R^{2}$ & 0.012 & 0.010 & 0.024 & 0.029 & 0.036 & 0.040 & 0.013 & 0.051 & 0.051 & 0.016 & 0.060 & 0.054 \\
\hline
\end{tabular}

